\title{
Interaction of uterine flushings with mouse blastocysts in vitro as assessed by the incorporation of $\left[{ }^{3} \mathrm{H}\right]$ uridine
}

\author{
C. O'Neill and P. Quinn \\ Department of Biological Sciences, University of Newcastle, \\ New South Wales 2308, Australia
}

\begin{abstract}
Summary. Culture of mouse blastocysts in medium supplemented with uterine flushings from mice at random stages of the oestrous cycle resulted in a depression of $\left[{ }^{3} \mathrm{H}\right]$ uridine incorporation. This depression was maintained for up to $12 \mathrm{~h}$, but by $24 \mathrm{~h}$ of culture, inhibition of uterine incorporation was no longer apparent. The loss of inhibition was due to a change in the activity of the flushings and not to a change in the ability of blastocysts to respond to the inhibitory influence. The inhibition of $\left[{ }^{3} \mathrm{H}\right]$ uridine incorporation was maintained for at least $24 \mathrm{~h}$ when blastocysts were transferred every $6 \mathrm{~h}$ to fresh uterine flushings.
\end{abstract}

\section{Introduction}

In many species of mammals, and in particular those displaying delayed implantation, there is a post-ovulatory phase of oestrogen secretion at a fixed period after ovulation. In the mouse, oestrogen secretion begins on Day 3 post coitum (p.c.) and reaches a peak on Day 4 p.c. between 10:00 and 12:00 h (McCormack \& Greenwald, 1974). In delayed implantation in rodents, induced by suckling of several young or ovariectomy, the secretion of 'nidatory' oestrogen does not occur and the blastocysts enter a state of metabolic dormancy. Ultrastructural signs of blastocyst activation are apparent within $8 \mathrm{~h}$ of an injection of oestrogen into ovariectomized pregnant mice treated with progesterone (Nilsson, 1974).

It is generally acknowledged that oestrogen secretion influences blastocyst activation at the time of implantation by altering the secretions of the uterus. The uterine secretions may act by containing an inhibitor during delayed implantation which is dissipated by the 'nidatory' oestrogen secretion or blastocyst activation at implantation may result from the production of activating substances which are absent during delayed implantation (McLaren, 1973; Psychoyos, 1973).

Several investigators have attempted to determine which of these proposals is correct by studying the effect of uterine secretions on blastocyst metabolism and development in vitro. Using flushings from non-pregnant animals which had the conditions of pseudopregnancy induced artificially by the administration of gonadotrophins and steroid hormones, Weitlauf (1976) found that secretions from 'implanting' and 'delayed implanting' animals caused a marked inhibition of $\left[{ }^{3} \mathrm{H}\right]$ uridine incorporation by mouse blastocysts. The inhibitory influence was concentration-dependent, dialysable and heat-resistant. Aitken (1977a, b) has shown that there is a dialysable factor which inhibits the hatching of the blastocyst from the zona pellucida in the uterine fluids of mice in delay. After dialysis fluids from mice implanting or with embryonic diapause are equally effective in promoting the hatching of blastocysts from the zona. Surani (1977) has reported similar findings but has also shown that fluids from implanting animals promote a significantly greater rate of blastocyst attachment than do those of animals with diapausing embryos. 
Despite these observations supporting the existence of a uterine inhibitor it has not yet been possible to assign to it a physiological role (Weitlauf, 1976; Surani, 1977). The present experiments were therefore undertaken to provide further information on this apparent inhibitory influence of uterine flushings on mouse blastocysts in vitro.

\section{Materials and Methods}

\section{Embryos}

All mice used were of the $\mathrm{F}_{1}$ hybrid cross $(\mathrm{C} 57 \mathrm{BL} \times \mathrm{CBA}$, or reciprocal) and were exposed to light from 07:30 to 21:30 h. Blastocysts were collected from 3-6-week-old females which had been induced to superovulate by an intraperitoneal injection of 5-10 i.u. PMSG (Folligon: Intervet) given at 15:00-17:00 h, followed $46-50 \mathrm{~h}$ later by an injection of the same dose of CG (Chorulon: Intervet). After the second injection, the females were placed with fertile males of the same $F_{1}$ hybrid type and checked the following morning for copulation plugs (= Day 1 of pregnancy). Blastocysts were recovered between 10:00 and 12:00 h on Day 4 of pregnancy. The medium used for collection and culture of blastocysts was that of Whitten (Medium $\mathrm{W}_{1}$ ) prepared as indicated by Hoppe \& Pitts (1973).

\section{Uterine fluids}

Females used as fluid donors were of the same $F_{1}$ hybrid type and 2-3 months old. Fluid donors were killed at random stages of the oestrous cycle, their uteri removed and flushed with $50 \mu \mathrm{l}$ of cold triple-distilled water, taking care not to introduce any contaminating fluid or cellular debris into the flushings, which were kept on ice during the collection period (Weitlauf, 1976).

Fluid from several animals was pooled and centrifuged at $70000 \mathrm{~g}$ for $1 \mathrm{~h}$ at $4^{\circ} \mathrm{C}$. The supernatant was decanted and its protein concentration determined by the method of Lowry, Rosebrough, Farr \& Randall (1951). Samples of flushings containing $15 \mu \mathrm{g}$ protein were pipetted into sterile glass tubes and frozen at $-20^{\circ} \mathrm{C}$. The samples were then freeze-dried and stored at $-76^{\circ} \mathrm{C}$ until use. The flushings were prepared for culture by the addition of $75 \mu \mathrm{l}$ Medium $\mathrm{W}_{1}$ (containing $3 \mathrm{mg} \mathrm{BSA} / \mathrm{ml}$ ) to give a final concentration of $200 \mu \mathrm{g}$ uterine protein/ml: this medium is referred to as Medium FL.

\section{Culture environment}

Ten blastocysts were cultured in $10 \mu \mathrm{l}$ drops of medium under $10 \mathrm{ml}$ of paraffin oil (Saybolt, Fisher Scientific Co., U.S.A.) in microtest plates (Falcon Plastics). The culture plates were incubated at $37^{\circ} \mathrm{C}$ in anaerobic gas jars that contained an humidified atmosphere of $5 \%$ $\mathrm{O}_{2}: 5 \% \mathrm{CO}_{2}: 90 \% \mathrm{~N}_{2}$.

Blastocysts were incubated in Medium $\mathrm{W}_{1}$ (control) or Medium FL for a given time, followed by a 30 -min incubation in Medium $\mathrm{W}_{1}$ containing $10 \mu \mathrm{M}-\left[5-{ }^{3} \mathrm{H}\right]$ uridine (sp. act. $28 \mathrm{Ci} / \mathrm{mmol}$ : Radiochemical Centre, Amersham, U.K.). Blastocysts were removed from the radioactive medium, washed three times $\left(1 \mathrm{ml} /\right.$ wash) in Medium $\mathrm{W}_{1}$ containing $1 \mathrm{mM}$ unlabelled uridine and stored at $-20^{\circ} \mathrm{C}$ for $1-3$ days until assayed.

\section{Extraction of RNA}

Samples were thawed and $0.2 \mathrm{ml}$ ice-cold mouse liver homogenate $(4 \mathrm{ml}$ of $0.25 \mathrm{M}$ sucrose containing $0.006 \mathrm{~N}-\mathrm{NaOH} / 1 \mathrm{~g}$ liver) was added to act as a carrier for labelled compounds. The acid-insoluble fraction was extracted with cold $20 \%$ trichloroacetic acid (TCA) 
for $30 \mathrm{~min}$. The precipitate was washed four times with $0.4 \mathrm{ml}$ cold $10 \%$ TCA. Further treatment with cold TCA did not reduce the amount of radioactivity and it is assumed that the acid-insoluble material contained the bulk of the radio-labelled RNA (Clegg \& Piko, 1977).

\section{Determination of radioactivity}

After the fourth $10 \%$ TCA wash, the precipitate of each sample was resuspended in $0.4 \mathrm{ml}$ $10 \%$ TCA and added to scintillation vials with $5 \mathrm{ml}$ toluene-Brydet $(2: 1 \mathrm{v} / \mathrm{v})$ containing $0.4(\mathrm{w} / \mathrm{v})$ 2,5-diphenyloxazole (PPO) and $0.01 \%$ phenyloxazolylphenyl-oxazolyl-phenyl (POPOP). Radioactivity in all samples was assayed by liquid scintillation spectrometry (Packard Tricarb counter, model 3255). The counting efficiency for each sample was determined by using a quench correction curve and the counts were converted to moles of $\left[{ }^{3} \mathrm{H}\right]$ uridine.

\section{Statistical analysis}

Each experiment was repeated three times and the values given in the text are means and standard errors of the means. Data were subjected to analysis of variance after logarithmic transformation. Differences between individual treatment means were tested by the NewmanKeuls multiple range test (Zar, 1974).

\section{Experiment 1}

\section{Results}

The ability of blastocysts to incorporate $\left[{ }^{3} \mathrm{H}\right]$ uridine after culture in the presence or absence of uterine flushings for a period of up to $24 \mathrm{~h}$ was investigated. Blastocysts were incubated in Medium $\mathrm{W}_{1}$ or Medium FL for $0,1 \cdot 5,3,6,12$ and $24 \mathrm{~h}$ and then transferred to Medium $\mathrm{W}_{1}$ containing $\left[{ }^{3} \mathrm{H}\right]$ uridine for $30 \mathrm{~min}$.

As shown in Text-fig. 1 , the incorporation of $\left[{ }^{3} \mathrm{H}\right]$ uridine by blastocysts in Medium $\mathrm{W}_{1}$ was constant over the first $12 \mathrm{~h}$. From 12 to $24 \mathrm{~h}$ there was a significantly $(P<0.01)$ increased incorporation. Blastocysts incubated in Medium FL displayed an immediate

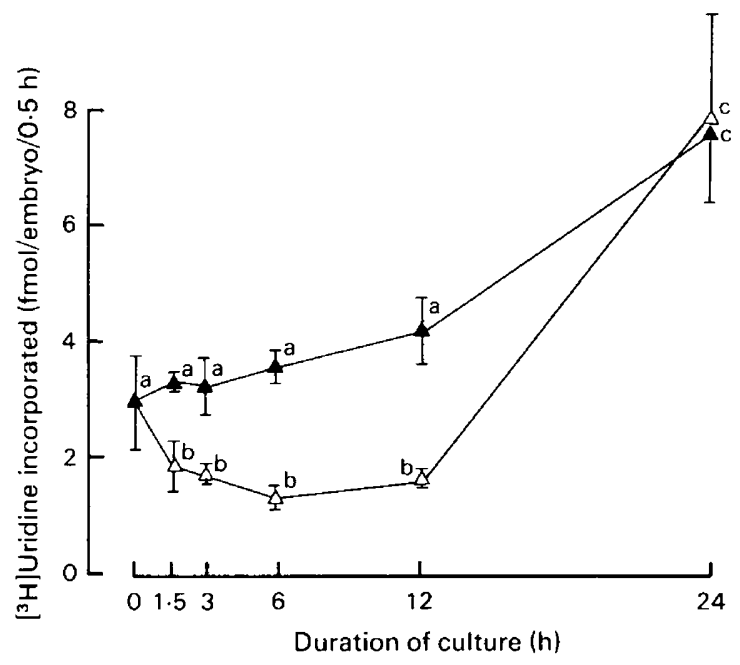

Text-fig. 1. The effect on mouse blastocysts of culture in Medium $W_{1}(\Delta)$ or Medium FL $(\triangle)$ as assessed by a subsequent 30 -min incubation in Medium $\mathrm{W}_{1}$ containing $\left[{ }^{3} \mathrm{H}\right]$ uridine. All points showing different letters are significantly different $(P<0.01)$, based on the NewmanKeuls multiple comparisons test. Each point represents the mean and s.e.m. of 3 replicates. 
depression of uridine incorporation. This depression reached a maximum after $1.5 \mathrm{~h}$ and was maintained for $12 \mathrm{~h}$ of culture. From 12 to $24 \mathrm{~h}$ there was a complete loss of inhibition of $\left[{ }^{3} \mathrm{H}\right]$ uridine incorporation and at $24 \mathrm{~h}$ there was no significant difference $(P>0.01)$ in the incorporation of $\left[{ }^{3} \mathrm{H}\right]$ uridine into blastocysts maintained in Medium $\mathrm{W}_{1}$ and those in Medium FL.

\section{Experiment 2}

This experiment was designed to determine whether the lost ability of Medium FL to depress uridine incorporation was dependent on the presence of blastocysts.

The following treatments were used. (a) Blastocysts were maintained in Medium $\mathrm{W}_{1}$ for $24 \mathrm{~h}$. (b) To determine whether the flushings used in this experiment were inhibitory, blastocysts were incubated in Medium FL for $3 \mathrm{~h}$. (c) The extent of loss of the inhibitory effect in the absence of blastocysts was determined by incubation of Medium FL for $21 \mathrm{~h}$ in the absence of blastocysts. Then 10 blastocysts, previously maintained in Medium $\mathrm{W}_{1}$, were placed in Medium FL for $3 \mathrm{~h}$. (d) To determine the extent of loss of the inhibitory effect in the presence of embryos, 10 blastocysts were incubated in Medium FL for $21 \mathrm{~h}$ and then replaced by 10 new blastocysts which were incubated for $3 \mathrm{~h}$.

After each of the above incubations, blastocysts were incubated in fresh Medium $\mathrm{W}_{1}$ containing $\left[{ }^{3} \mathrm{H}\right]$ uridine for $30 \mathrm{~min}$, and the uridine incorporation was assayed.

Previous exposure of uterine flushings to Day 4 blastocysts for $21 \mathrm{~h}$ significantly $(P<0.01)$ reduced the ability of the fushings to inhibit uridine incorporation into a second group of blastocysts, whereas the inhibitory activity of flushings was maintained over this period in the absence of blastocysts (Table 1).

Table 1. The effect of previous exposure of uterine flushings to mouse blastocysts on the ability of these flushings to inhibit $\left[{ }^{3} \mathrm{H}\right]$ uridine incorporation

\begin{tabular}{|c|c|}
\hline Treatment* & $\begin{array}{c}{ }^{3} \mathrm{H} \mid \text { Uridine incorporation } \\
(\mathrm{fmol} / 30 \mathrm{~min} / \mathrm{embryo}) \dagger\end{array}$ \\
\hline Medium $W_{1}$ for $24 h$ & $6.96 \pm 1.93^{a}$ \\
\hline Medium FL for $3 \mathrm{~h}$ & $1.67 \pm 0.20^{b}$ \\
\hline Medium FL for $24 \mathrm{~h}$ & $5 \cdot 45 \pm 1 \cdot 10^{\mathrm{a}}$ \\
\hline $\begin{array}{l}\text { Medium FL (- embryos) } 21 \mathrm{~h} \text {; fresh } \\
\text { embryos for } 3 \mathrm{~h}\end{array}$ & $1.59 \pm 0.85^{b}$ \\
\hline $\begin{array}{l}\text { Medium FL ( }+ \text { embryos) } 21 \mathrm{~h} \text {; fresh } \\
\text { embryos for } 3 \mathrm{~h}\end{array}$ & $5 \cdot 37 \pm 0 \cdot 70^{\mathrm{a}}$ \\
\hline
\end{tabular}

\footnotetext{
* After each incubation embryos were transferred to Medium $\mathrm{W}_{1}$ containing $10 \mu \mathrm{M}-\left[{ }^{3} \mathrm{H}\right]$ uridine for $30 \mathrm{~min}$.

† Values are mean \pm s.e.m. for 3 replicates per treatment, 10 embryos per replicate. Values with different superscripts are significantly different $(P<0.01)$.
}

\section{Experiment 3}

To investigate whether the inhibition could be maintained by frequent changes of blastocysts to media containing fresh uterine flushings, blastocysts were treated as follows: (i) cultured in Medium $\mathrm{W}_{1}$ for 6 or $24 \mathrm{~h}$; (ii) cultured in Medium FL for 6 or $24 \mathrm{~h}$; (iii) transferred to a fresh $10 \mu \mathrm{l}$ drop of Medium $\mathrm{W}_{1}$ every $6 \mathrm{~h}$ for $24 \mathrm{~h}$; and (iv) transferred to a fresh $10 \mu \mathrm{l}$ drop of Medium FL every $6 \mathrm{~h}$ for $24 \mathrm{~h}$.

The blastocysts were then transferred to fresh Medium $\mathrm{W}_{1}$ containing $\left[{ }^{3} \mathrm{H}\right]$ uridine and the incorporation of label was assayed.

The results in Table 2 show that continual transfer of blastocysts to fresh uterine flushings maintains the inhibition of uridine incorporation over $24 \mathrm{~h}$ in culture, while incubation in the same flushings for $24 \mathrm{~h}$ results in a loss of inhibition. 
Table 2. Incorporation of $\left[{ }^{3} \mathrm{H}\right]$ uridine into mouse blastocysts after various culture manipulations

\begin{tabular}{lc}
\hline \multicolumn{1}{c}{ Treatment } & $\begin{array}{c}\left.{ }^{3} \mathrm{H}\right] \text { Uridine incorporation } \\
\text { (fmol/30 min/embryo) } \dagger\end{array}$ \\
\hline (i) Medium $\mathrm{W}_{1}$ for $6 \mathrm{~h}$ & $6.38 \pm 0.69^{\mathrm{a}}$ \\
$24 \mathrm{~h}$ & $6.69 \pm 1.19^{\mathrm{a}}$ \\
(ii) Medium $\mathrm{FL}$ for $6 \mathrm{~h}$ & $1.16 \pm 0.21^{\mathrm{b}}$ \\
Medium FL for $24 \mathrm{~h}$ & $7.39 \pm 2.07^{\mathrm{a}}$ \\
(iii) Medium $\mathrm{W}_{1}$ for $24 \mathrm{~h}$, changed every & $5.43 \pm 0.76^{\mathrm{a}}$ \\
$6 \mathrm{~h}$ & $1.43 \pm 0.47^{\mathrm{b}}$ \\
(iv) Medium FL for $24 \mathrm{~h}$, changed every & \\
$6 \mathrm{~h}$ & \\
\hline
\end{tabular}

* After each treatment embryos were transferred to Medium $\mathrm{W}_{1}$ containing $10 \mu \mathrm{M}-\left[{ }^{3} \mathrm{H}\right]$ uridine for $30 \mathrm{~min}$.

$\dagger$ Values are mean \pm s.e.m. for 3 replicates per treatment, 10 blastocysts per replicate. Values with different superscripts are significantly different $(P<0.01)$.

\section{Discussion}

Uterine flushings from random stages of the oestrous cycle cause an initial rapid depression of $\left[{ }^{3} \mathrm{H}\right]$ uridine incorporation. This inhibition is maintained for $12 \mathrm{~h}$ with a subsequent return to normal metabolism. Weitlauf (1976) reported the inhibitory effect of flushings over $6 \mathrm{~h}$, but the loss of the inhibitory effect by $24 \mathrm{~h}$ has not previously been reported.

This finding demonstrates an inherent difficulty associated with studies of the effect of uterine flushings on the embryo in vitro, in that only a static sample of uterine secretions can be tested (Surani, 1977). Such a static sample does not take into account the dynamic nature of the uterine secretions. The composition of the uterine environment would be affected by continual selective secretion and selective reabsorption of components by the endometrium together with interactions with the embryo (Enders \& Given, 1977). Experiments involving extended culture of uterine secretions are therefore unlikely to give valid results.

The reason for the loss of the inhibitory influence after $24 \mathrm{~h}$ might be due to (1) the lability of the inhibitory factor, (2) the ability of the blastocyst to neutralize the inhibitor, or (3) an alteration of the metabolism of the blastocyst so that it no longer responds to the effects of the inhibitor. Table 1 demonstrates that in the absence of blastocysts for $21 \mathrm{~h}$ the uterine flushings retain their ability to inhibit $\left[{ }^{3} \mathrm{H}\right]$ uridine incorporation. Therefore, the loss of inhibition is not due to the lability of the active components. The results in Table 2 demonstrate that transfer of blastocysts to fresh flushings every $6 \mathrm{~h}$ for $24 \mathrm{~h}$ maintains the inhibition for $24 \mathrm{~h}$. If the embryo is capable of changing its metabolism to overcome the inhibitory effect, then it would be expected to occur irrespective of the medium changes, and so we conclude that blastocysts have the ability to neutralize the inhibitory influence of flushings. Continual transfer of blastocysts to fresh flushings would, to some extent, overcome the problem of testing static samples. It can be assumed that this situation provides a better representation of the situation in vivo.

The biochemical nature of the inhibitor is yet to be determined. Weitlauf (1976) has shown that the effect can be removed by dialysis, is stable after heating to $90^{\circ} \mathrm{C}$ and is concentration dependent. Psychoyos (1973) has suggested that the inhibitor in rat uterine fluids is a lipid. It is premature to speculate on possible mechanisms of blastocyst neutralization of the inhibitor until its biochemical nature is determined. Aitken's (1977a) suggestion that the presence of unlabelled uridine in the uterine fluids may be responsible for the apparent inhibition of uridine incorporation warrants further investigation. However, the fact that the inhibitor also affects blastocyst hatching (Aitken, 1977b; Surani, 1977) is unlikely to be related to the presence of unlabelled uridine. 
The rates of $\left[{ }^{3} \mathrm{H}\right]$ uridine incorporation presented here do not indicate the rates of RNA synthesis, since no consideration has been given to possible changes in the endogenous pool size of uridine or its metabolites. Rather they simply indicate an alteration in the utilization of the uridine by blastocysts in the presence of flushings. This may be due to changes in the membrane transport of the nucleoside, the rate of phosphorylation of the nucleoside, a reduced incorporation into macromolecules or a combination of these factors. Hence, the present results do not permit definition of the mode of action of the inhibitor.

It has previously been assumed that the blastocyst plays a totally passive role during delayed implantation and subsequent blastocyst activation (Aitken, 1977a). Yet our results show that in vitro the blastocyst is capable of modifying the effects of uterine flushings. Camus, Lejeune \& Leroy (1979) have proposed a model for blastocyst activation which involves 'nidatory' oestrogen secretion causing the dissipation of a uterine inhibitor. Our results suggest that the blastocyst may also have a role in this dissipation. The involvement of the blastocyst may well explain the inability of Weitlauf (1976) to show a loss of inhibition from fluids of 'pseudopregnant' 'implanting' mice. The differences in the inhibitory activity between artificial 'pseudopregnancy', pseudopregnancy and pregnancy are presently being examined to determine the significance of embryo presence in utero on the inhibitory activity of uterine secretions.

We thank Dr Anne McLaren F.R.S. for her advice and comments on the manuscript and Dr R. N. Murdoch for his helpful discussions. C. O'N. was supported by an Australian Commonwealth Postgraduate Scholarship.

\section{References}

Aitken, R.J. (1977a) Embryonic diapause. In Development in Mammals, vol. 1, pp. 307-359. Ed. M. H. Johnson. North Holland Publishing Co., Amsterdam.

Aitken, R.J. (1977b) The culture of mouse blastocyst in the presence of uterine flushings collected during normal pregnancy, delayed implantation and prooestrus. J. Embryol. exp. Morph. 41, 295-300.

Camus, M., Lejeune, B. \& Leroy, F. (1979) Induction of implantation in the rat by intraparametrial injection of actinomycin D. Biol. Reprod. 20, 11151118.

Clegg, K.B. \& Piko, L. (1977) Size and specific activity of the UTP pool and overall rates of RNA synthesis in early mouse embryos. Devl Biol. 58, 76-95.

Enders, A.C. \& Given, R.L. (1977) The endometrium of delayed and early implantation. In Biology of the Uterus, pp. 203-243. Ed. R. M. Wynn. Plenum Press, New York.

Hoppe, P.C. \& Pitts, S. (1973) Fertilization in vitro and development of mouse ova. Biol. Reprod. 8, $420-426$.

Lowry, O.H., Rosebrough, N.J., Farr, A.L. \& Randall, R.J. (1951) Protein measurement with the Folin phenol reagent. J. biol. Chem. 193, 265-275.

McCormack, J.T. \& Greenwald, G. (1974) Evidence for preimplantation rise in oestradiol- $17 \beta$ on Day 4 of pregnancy in the mouse. J. Reprod. Fert. 41, 297301.

McLaren, A. (1973) Blastocyst activation. In The Regulation of Mammalian Reproduction, pp. 321-328. Eds S. J. Segal, R. Crozier, P. A. Corfman \& P. G. Condliffe. C. C. Thomas, Springfield.

Nilsson, B.O. (1974) The morphology of blastocyst implantation. J. Reprod. Fert. 39, 187-194.

Psychoyos, A. (1973) Endocrine control of egg implantation. In Handbook of Physiology, Section 7, Vol. II, part 2, pp. 201-256. Eds R. O. Greep \& E. B. Astwood. American Physiological Society, Washington D.C.

Surani, M.A.H. (1977) Cellular and molecular approaches to blastocyst-uterine interaction at implantation. In Development in Mammals, vol. 1, pp. 245-305. Ed. M. H. Johnson. North Holland Publishing Co., Amsterdam.

Weitlauf, H.M. (1976) Effect of uterine flushings on RNA synthesis by "implanting" and "delayed implanting" mouse blastocysts in vitro. Biol. Reprod. 14, 566-571.

Zar, J.H. (1974) Biostatistical Analysis. Prentice-Hall, Inc., Englewood Cliffs.

Received 27 October 1980 